\title{
CHALLENGES AND OPPORTUNITIES OF MEDICAL EDUCATION UNDER CONDITIONS OF CORONAVIRUS DISEASE (COVID-19) PANDEMIA
}

\author{
I.M. Poiasnyk, V.A. Gryb \\ Ivano-Frankivsk National Medical University, Ivano-Frankivsk, Ukraine
}

The article analyzes how higher medical education is currently undergoing a gradual but significant change to the transformation into online learning adapt accordingly in order to fulfill the core competencies of medical training and to provide quality education to medical students during the COVID-19 pandemia.

Objective - to study the challenges and opportunities faced by medical schools in introduction of the remote learning for basic science teaching in response to the COVID-19 crisis.

Conclusions. Despite the pace of this transition, both formal and informal student feedback indicated that students have an extremely high level of satisfaction and engagement with online learning activities. The use of emergent technology (e.g., artificial intelligence for adaptive learning, virtual simulation, and telehealth) for education is most likely to be indispensable components of transformative change and post-COVID medical education. These measures could then be followed by hands-on experience that is provided in a safe environment. As physicians begin to use telehealth (phone calls, video visits, and communication over online medical record applications) to communicate with their patients, students should be included (and instructed) in this learning environment. It is likely that telehealth will persist long after the pandemic recedes perhaps even as a preferred method of physician-patient interaction in some situations. Therefore, it is essential that students graduate from medical school well trained in telehealth including technological aspects as well as learning the most professional models of the physician-patient distance interaction.

\section{ВИКЛИКИ ТА МОЖЛИВОСТІ МЕДИЧНОЇ ОСВІТИ В УМОВАХ ПАНДЕМЇ̈ COVID-19}

\section{І.М. Поясник, В.А. Гриб}

У статті проаналізовано інтеграцію онлайн-навчання у вищих навчальних медичних закладах для забезпечення виконання основних компетениій медичної підготовки та надання якісної освіти студентам-медикам під час пандемї COVID-19.

Мета роботи - вивчити виклики та можливості, з якими стикаються медичні иколи при впровадженні дистанційного навчання для викладання базових наук у відповідь на кризу, спричинену COVID-19.

Висновки. Незважаючи на темпи цьього переходу як офіційні, так і неформальні відгуки студентів вказували на те, щсо студенти мають надзвичайно високий рівень задоволеності та залученості до навчання в онлайн-режимі. Використання нових технологій (наприклад, штучного інтелекту для адаптивного навчання, віртуального моделювання та телемедицини) для освіти буде неодмінним компонентом трансформаційних змін та медичної освіти після закінчення пандемії COVID-19. Оскільки лікарі починають використовувати телемедицину (телефонні дзвінки, відеовідвідування та спілкування через онлайн-програми медичних записів) для спілкування зі своїми пацієнтами, студенти повинні бути включені у изе навчальне середовище ( $і$ належним чином проінструктовані).

\section{ВЫЗОВЫ И ВОЗМОЖНОСТИ МЕДИЦИНСКОГО ОБРАЗОВАНИЯ В УСЛОВИЯХ ПАНДЕМИИ COVID-19}

\section{И.М. Пояснык, В.А. Грыб}

В статье проанализирована интеграция онлайн-обучения в выссиих учебных медицинских заведениях для обеспечения выполнения основных компетенций медицинской подготовки и предоставления качественного образования студентаммедикам во время пандемии COVID-19.

Цель работы - изучить вызовы и возможности, с которыми сталкиваются

\section{Key words:}

COVID-19 pandemic, online learning, remote learning, challenges, opportunities.

Clinical and experimental pathology 2021. Vol.20, № 3 (77). P. 89 - 95.

DOI:10.24061/1727-4338. XX.3.77.2021.13

E-mail: sof.3425@gmail.com
Ключові слова: пандемія COVID-19, онлайн-навчання, дистанціийне навчання, проблеми, можливості.

Клінічна та експериментальна патологія 2021. T.20, №3 (77). C. 89 - 95. 
медиичнские школь при внедрении дистанционного обучения для преподавания базовых наук в ответ на кризис, вызванный COVID-19.

Выводы. Несмотря на темпы этого перехода какофициальные, таки неформальные отзывы студентов указывали на то, что студенты имеют чрезвычайно высокий уровень удовлетворенности и вовлеченности в обучение в онлайн-режиме. Использование новых технологий (например, искусственного интеллекта для адаптивного обучения, виртуального моделирования и телемедицины) для образования будет непременным компонентом трансформационных изменений и медицинского образования после окончания пандемии COVID-19. Поскольку врачи начинают использовать телемедицину (телефонные звонки и общение через онлайн-программы медицинских записей) для общения со своими пациентами, студенты должны быть включены в эту учебную среду (и надлежашим образом проинструктированы).

\section{Introduction}

COVID-19 has caused unprecedented disruption to the medical education process and to healthcare systems worldwide [1]. The COVID-19 pandemic puts people at risk of developing life-threatening conditions, presenting substantial challenges for medical education, as instructors must deliver lectures safely, while also ensuring the integrity and continuity of the medical education process [2]. The highly contagious nature of the virus has made it difficult to continue lectures as usual, thus influencing the medical education process, which is based on lectures and patient-based education [3]. These challenges have resulted in limited patient care due to the focus on COVID-19 patients, which restricts the availability of bedside teaching opportunities for medical students. Consequently, they are unable to complete their clerkships [2]. Medical training through clinical rotations has been suspended [4]. Other challenges include a fear that medical students may contract the virus during their training and may transmit it to the community [5]. Additionally, students are required to stay at home and to abide by social distancing guidelines. Therefore, we must develop a medical education curriculum that provides students with opportunities for continuous learning, while also avoiding delays due to the pandemia [6].

\section{Objective}

Of this review paper is to examine the challenges and opportunities faced by medical schools in implementing remote learning for basic science teaching in response to the COVID-19 crisis.

\section{Main part}

The pandemia has provided opportunities for staff to acquire skills in online pedagogy and digital media production while developing alternative modes of assessments and transferring principles of learning [7-9]. Online learning during COVID-19 received positive students' feedback with "an extremely high level of satisfaction and engagement with online learning activities" 1 and brought a psychological resilience among staff and students $[10,11]$. This is an opportunity for the academic sector to converge, strengthen connections across countries and continents, and collaborate. Medical schools, regulatory bodies, and other stakeholders have a responsibility to ensure that tomorrow's doctors are "sufficiently trained and supported to deliver essential patient care, even in crises" [12]. Medical educators should "learn from this experience and prioritize a forward-thinking and scholarly approach" to implement best practices and flexible approaches adopted in medical education around the world for an effective transition to online learning and assessment [13]. As pandemia exposed the "flaws" in medical education and healthcare, medical educators should review curriculum using the "bioscientific model of health" and widen the educational approach by incorporating determinants of health (behavioral, social, and environmental factors). Medical curriculum should include "surveillance for disease, investment in disease and injury prevention, and disaster planning" as core components [14]. We must remain optimistic as the medical education fraternity has accepted that "transition is inevitable" and has already started preparing to ensure that "transition can be smooth through resilient educational systems" [15].

As medicine is a continuously evolving subject, medical service is a field that requires continuous up-gradation of knowledge for providing optimal health care to the patients. This pandemic called for a rapid transition to E-education for many health care professionals. Students had been removed from direct patient care activities and lectures. We needed to accept our new reality or "new normal" of learning was moving online to create the best experience possible to keep the medical fraternity on track for progression. E-education platforms such as digital conferences, webinars, etc. gave us unique opportunities to engage with both peers and mentors. These opportunities also helped in offsetting the impact of physical and social distancing [16].

The academic leadership has been placed under tremendous pressure in terms of delivery, access, and assessment of courses; while simultaneously preserving the principles of integrity, equity and inclusiveness, fairness, ethics, and safety [9, 17-20]. The unprecedented use of online pedagogy as an emergency measure during COVID-19 period, with an adaptation to the "new normal" to deliver preclinical medical education, has brought both challenges and opportunities to medical education [21-24]. The main impediments to providing online learning include lack of reliable network infrastructure (hardware and software, network bandwidth) and compatible online platforms that work 
with existing learning management system (LMS). Other challenges included shortage of competent IT personnel to extend technical support, zoom-bombing/cyberattacks on online platforms, increased cost (schools, students, and faculty), time constraints, poor computer technical skills of faculty and students, inadequate infrastructure and resources, and absence of institutional policies, which will pose real challenges for low- and middleincome countries [7, 17-18, 20].

While COVID-19 has thrown many challenges for preclinical medical education, it has also created opportunities - academic leaders with servant leadership, distribution of leadership responsibilities, and clear lines of communication dealt with the situation aptly [7-6, 17]. Online delivery of courses has the potential to enhance student engagement, geographical accessibility, and synchronous/asynchronous learning and assessment [25, 26]. Sophisticated technology is readily available which should provide excellent alternatives to the existing traditional methods of education and learning. The main difference between traditional and technology-based educational sessions is that the latter allow students to undertake the learning in their own time and in their preferred location [27]. By playing the lecture at double speed, most students "get" the content of a 60-minute class in 30 minutes. They can rewind and review multiple times any portion of the lecture they did not fully grasp the first time through. This approach saves students time, provides greater flexibility, and allows more attention to the topics they find difficult. They can group similar lectures together, rewatch them, take breaks while watching, and view the lectures with small groups of other students [28].

Online education programs, according to Ezekiel J. Emanuel, can also offer opportunities for interactive sessions such as synchronous question-and-answer sessions with faculty as well as student discussion groups. With more seamless, reliable technology and, more importantly, advances in augmented reality and virtual reality, it will soon be possible to "feel" as if everyone in a virtual group is in the same room participating in a single discussion. In addition, histology lectures and slides are already largely online, and digital simulations for anatomy dissection are already available and will improve with virtual reality [28]. A good example is Zoom - an online meeting tool that can be used for education. It allows students to either attend the educational session face to face or access it in real-time from any location. It also allows synchronous sessions and the participation of multiple users at the same time. However, Zoom teaching sessions can be disrupted by technological difficulties, particularly in areas with poor Wi-fi or for students in countries with less internet infrastructure. The provider of the teaching session needs to plan for the learning curve required for students to use Zoom effectively, and not assume that all students have the required practical knowledge to use this [27].

The current situation also raised concerns regarding unlimited amount of time spent in front of the computer, lack of social interaction, and lack of real-life verbal and nonverbal communication which could result in a passive form of learning [7, 13, 19, 21-24]. Moreover, Клінічна та експериментальна патологія. 2021. Т.20, № 3 (77) facial expression and voice would be compromised in online teaching to some extent. Online learning will minimize the chances of building a better mentoring relationship between faculty and students as well. Nalini Pather et al., consider that the lack of hands-on training in the preclinical years may have serious implications on the training of the current cohort of preclinical students, and they may struggle later in the clinical years [2124]. It is well established that clerking patients cannot be replaced by online learning as "clinical experience and human interaction are extremely important for the practice of medicine" and online learning cannot completely replace in-person live sessions. Clinical students can be benefited when teaching is supplemented by virtual simulations and computer-based models [29].

Amir H. Sam et al., proposed solutions that pertained to interactive online discussions about cases. In this method, students are initially granted a weekly series of immersive online cases to model a clinical role. They then use an online platform to present a review of the patient's history, findings from the physical examination, results of investigations, and proposed management plans. Next, the topic is addressed during an online webinar with a teaching physician, and students can pose questions using a specific online platform. This visual interface will simulate bedside teaching [30].

Woolliscroft proposed method to tackle the challenges pertaining to medical education is the use of telemedicine, which has been around for several decades. In contrast to an in-person clinical visit, telemedicine involves a virtual visit, and it can play a major role in teaching medical students and helping them to acquire clinical experience by interacting with real patients, under the supervision of attending physicians [1]. Furthermore, Judd E Hollander found that virtual clinical experience offer advantages for patients, as it is provided with ease and allows for connectivity without the risk of infection transmission. It would be beneficial if clinicians had the opportunity to treat to people with severe and chronic conditions, and if the workload of physicians could be reduced, especially during an outbreak [31]. In a recent study conducted in the area of emergency medicine clerkships, students' provided positive feedback regarding a virtual clinical experience that involved direct participation in patient care under the clinicians' supervision [32].However, on the mind of Ahmed Alsoufi et al., this approach requires further evaluation, and more support is needed for its official implementation in medical schools; only $21.1 \%$ of the participants in our study supported the use of e-learning for clinical aspects, while 54.8\% disagreed about the use of this approach. However, these proposed learning approaches should follow a systematic curriculum that is developed by experts, and which includes the establishments of goals, educational strategies, implementation methods, and evaluation processes to ensure that the intended learning goals are met. Further, as students at different levels of learning have different needs and objectives, such programs should address students' needs and goals, as well as they university's objectives [33].

Nevertheless, medical care will remain largely an in-person, face-to-face interaction between patients ISSN 1727-4338 https://www.bsmu.edu.ua 
and physicians or other clinicians. Consequently, the clinical portion of medical education will remain focused on hospitals, physician offices, patients' homes, and other settings. The most pivotal aspect of teaching in these setting occurs in the apprenticeship model, in which an experienced physician and student share clinical situations and the imparting of knowledge and learning are inextricably woven into the actual caring for the patient. Medical schools are uniquely capable of organizing these experiences of clinical rotations with skilled mentors. The irreducible core role for medical schools will be organizing and overseeing clinical education [28].

Most of the studies previously mentioned that a large number of medical students, irrespective of their level of training, have benefitted from this extra time by focusing on their professional development and engaging in leadership and volunteering opportunities. Eagerly waiting to be at the service of others, some of us are helping health care workers with contact tracing while others are involved in discussing COVID-19 test results with patients over the phone [34].

Another challenge for the medical education process is examinations. Some schools, such as the Imperial College in London, started to implement an online examination platform during the COVID-19 pandemic for final-year medical students to prevent any further disruption and postponement of student graduations [35, 36]. This form of online examination and assessment was proposed to meet the requirement for board and fellowship examinations [37]. Albeit, it poses several technical issues, such as the availability of specific technical requirements including cameras, microphones, and speakers with specific features, so as to prevent any disruption and bias. Besides, it poses ethical challenges, and several difficulties are encountered in terms of its implementation such as risks of leaked questions, which would prevent an accurate in-person assessment [33].

\section{Conclusions}

Taking into account the challenges teachers and students of medical universities encountered, they managed to provide adequate levels of e-learning knowledge, attitudes, and practice. This evidences the usability of this teaching method in a country with limited resources despite the technical and socioeconomic challenges faced. Extensive educational support should be provided to medical students, especially during the pandemic. Our study is also in line with other studies $[31,34]$ which suggest that adapting interactive online learning lectures by using highly sophisticated technologies along with virtual clinical experience to combine clinical scenarios with similar bedside teaching based on discussions of medical cases. Additionally, the situation should be assessed further to examine whether online examinations can help avoid postponing student graduations and medical training. The COVID-19 pandemia is ongoing and will continue to disrupt medical education and training. COVID-19 has overloaded the healthcare system and has affected the ability of healthcare providers to provide adequate healthcare services [33].

\section{Список літератури}

1. Woolliscroft JO. Innovation in Response to the COVID-19 Pandemic Crisis. Acad Med. 2020;95(8):1140-2. doi: 10.1097/ ACM.0000000000003402

2. Calhoun KE, Yale LA, Whipple ME, Allen SM, Wood DE, Tatum RP. The impact of COVID-19 on medical student surgical education: Implementing extreme pandemic response measures in a widely distributed surgical clerkship experience. Am J Surg. 2020;220(1):44-7. doi: 10.1016/j.amjsurg.2020.04.024

3. Sklar DP. COVID-19: Lessons From the Disaster That Can Improve Health Professions Education. Acad Med. 2020;95(11):1631-3. doi: 10.1097/ACM.0000000000003547

4. Akers A, Blough C, Iyer MS. COVID-19 Implications on Clinical Clerkships and the Residency Application Process for Medical Students. Cureus [Internet]. 2020[cited $2021 \mathrm{Sep}$ 27];12(4):e7800. Available from: https://www.ncbi.nlm.nih.gov/ pmc/articles/PMC7243841/pdf/cureus-0012-00000007800.pdf doi: $10.7759 /$ cureus. 7800

5. Khasawneh AI, Humeidan AA, Alsulaiman JW, Bloukh S, Ramadan M, Al-Shatanawi TN, et al. Medical Students and COVID-19: Knowledge, Attitudes, and Precautionary Measures. A Descriptive Study From Jordan. Front Public Health [Internet]. 2020 [cited 2021 Sep 30];8:253. Available from: https://www.ncbi. nlm.nih.gov/pmc/articles/PMC7274076/pdf/fpubh-08-00253.pdf doi: $10.3389 /$ fpubh.2020.00253

6. Ross DA. Creating a "Quarantine Curriculum" to Enhance Teaching and Learning During the COVID-19 Pandemic. Acad Med. 2020;95(8):1125-6. doi: 10.1097/ACM.0000000000003424

7. Longhurst GJ, Stone DM, Dulohery K, Scully D, Campbell T, Smith CF. Strength, Weakness, Opportunity, Threat (SWOT) analysis of the adaptations to anatomical education in the United Kingdom and Republic of Ireland in response to the Covid-19 pandemic. Anat Sci Educ. 2020;13(3):301-11. doi: 10.1002/ ase. 1967

8. Fernandez AA, Shaw GP. Academic leadership in a time of crisis: the coronavirus and COVID-19. J Leadersh Stud. 2020;14(1):3945. doi: $10.1002 / \mathrm{jls} .21684$

9. The University of the West Indies. UWI shares changes to teaching, exams amid COVID-19 [Internet]. Loop News; 2020[cited 2021 Sep 25]. Available from: https://tt.loopnews. $\mathrm{com} /$ content/uwi-shares-changes-teaching-exams-amid-covid-19

10. Yurttas IS, Aktar I, Bardak M, Goeschl S. Institutional report for COVID-19 impact on medical education [Internet]. European Medical Students' Association; 2020[cited 2021 Sep 27]. Available from: https://medisep.org/mediblog-blog 10

11. Dedeilia A, Sotiropoulos MG, Hanrahan JG, Janga D, Dedeilias $\mathrm{P}$, Sideris M. Medical and surgical education challenges and innovations in the COVID-19 era: a systematic review. In Vivo. 2020;34(3 Suppl):1603-11. doi: 10.21873/invivo.11950

12. Representatives of the STARSurg Collaborative. Medical student involvement in the COVID-19 response. Lancet. 2020;395(10232):1254. doi: 10.1016/S0140-6736(20)30795-9

13. Rose S. Medical student education in the time of COVID-19. JAMA. 2020;323(21):2131-2. doi: 10.1001/jama.2020.5227

14. Stowell JR, Bennett D. Effects of online testing on student exam performance and test anxiety. J Educ Comput Res. 2010;42(2):161-71. doi: 10.2190/EC.42.2.b

15. Wolanskyj-Spinner AP. COVID-19: the global disrupter of medical education [Internet]. 2020[cited $2021 \mathrm{Sep} 30$ ]. Available from: https://www.ashclinicalnews.org/viewpoints/editorscorner/covid-19-global-disrupter-medical-education/

16. Waghmare PP, Gupta A. Challenges and Solutions to Continuing Medical Education amid Novel Coronavirus Disease (COVID-19)

Клінічна та експериментальна патологія. 2021. Т.20, № 3 (77) 
Pandemic and National Lockdown in India. MedEdPublish [Internet]. 2020[cited 2021 Sep 27]. Available from: https:// www.mededpublish.org/manuscripts/3346 doi: 10.15694/ mep.2020.000219.1

17. Torda AJ, Velan G, Perkovic V. The impact of Covid-19 pandemic on medical education. Med J Aust. 2020;213(7):334. doi: $10.5694 / \mathrm{mja} 2.50762$

18. Goh PS, Sandars J. A vision of the use of technology in medical education after the COVID-19 pandemic. MedEdPublish [Internet]. 2020[cited 2021 Sep 27];9(1):49. Available from: https:/www.mededpublish.org/manuscripts/2943 doi: 10.15694/ mep.2020.000049.1

19. Gallagher TH, Schleyer AM. "We signed up for this!" Student and trainee responses to the Covid-19 pandemic. $N$ Engl J Med [Internet]. 2020[cited 2021 Sep 30];382(25):e96. Available from: https://www.nejm.org/doi/pdf/10.1056/ NEJMp2005234?articleTools=true doi: $10.1056 /$ nejmp2005234

20. Liang ZC, Ooi SBS, Wang W. Pandemics and their impact on medical training: lessons from Singapore. Acad Med [Internet]. 2020[cited 2021 Sep 25];20(10). Available from: https://www. ncbi.nlm.nih.gov/pmc/articles/PMC7188065/ doi: 10.1097/ ACM.0000000000003441

21. Pather N, Blyth P, Chapman JA, Dayal MR, Flack NAMS, Fogg QA, et al. Forced disruption of anatomy education in Australia and New Zealand: an acute response to the Covid-19 pandemic. Nat Sci Educ. 2020;13(3):284-300. doi: 10.1002/ase.1968

22. Franchi T. The impact of the Covid-19 pandemic on current anatomy education and future careers: a student's perspective. Anat Sci Educ. 2020;13(3):312-5. doi: 10.1002/ase.1966

23. Doubleday EG, O'Loughlin VD, Doubleday AF. The virtual anatomy laboratory: usability testing to improve an online learning resource for anatomy education. Anat Sci Educ. 2011;4(6):31826. doi: 10.1002 /ase. 252

24. Saverino D. Teaching anatomy at the time of COVID-19. Clin Anat [Internet]. 2020[cited 2021 Sep 30]. Available from: https:// www.ncbi.nlm.nih.gov/pmc/articles/PMC 7267360/pdf/CA9999-na.pdf doi: 10.1002/ca.23616

25. Bao W. COVID-19 and online teaching in higher education: a case study of Peking University. Hum Behav Emerg Technol. 2020;2(2):113-5. doi: 10.1002/hbe2.191

26. Watson A, McKinnon T, Prior S-D, Richards L, Green CA. COVID-19: time for a bold new strategy for medical education. Med Educ Online [Internet]. 2020[cited 2021 Sep 27];25(1):1764741. Available from: https://www.ncbi.nlm.nih. gov/pmc/articles/PMC7269071/pdf/ZMEO_25_1764741.pdf doi: $10.1080 / 10872981.2020 .1764741$

27. Samaraee AA. The impact of the COVID-19 pandemic on medical education. Br J Hosp Med (Lond). 2020;81(7):1-4. doi: 10.12968/hmed.2020.0191

28. Emanuel EJ. The Inevitable Reimagining of Medical Education. JAMA. 2020;323(12):1127-8. doi: 10.1001/jama.2020.1227

29. Candler C. Effective use of educational technology in medical education. Colloquium on educational technology: recommendations and guidelines for medical educators Washington: Association of American Medical Colleges; 2007. 19 p.

30. Sam AH, Millar KR, Lupton MGF. Digital Clinical Placement for Medical Students in Response to COVID-19. Acad Med [Internet]. 2020[cited 2021 Sep 25]. Available from: https://www. ncbi.nlm.nih.gov/pmc/articles/PMC7179062/ doi: 10.1097/ ACM.0000000000003431

31. Hollander JE, Carr BG. Virtually Perfect? Telemedicine for Covid-19. N Engl J Med. 2020;382(18):1679-81. doi: 10.1056/ nejmp2003539

Клінічна та експериментальна патологія. 2021. Т.20, № 3 (77)
32. Chandra S, Laoteppitaks C, Mingioni N, Papanagnou D. ZoomingOut COVID: Virtual Clinical Experiences in an Emergency Medicine Clerkship. Medical Education. 2020;54(12):11823. doi: $10.1111 /$ medu. 14266

33. Alsoufi A, Alsuyihili A, Msherghi A, Elhadi A, Atiyah H, Ashini A, et al. Impact of the COVID-19 pandemic on medical education: Medical students' knowledge, attitudes, and practices regarding electronic learning. PLoS One [Internet]. 2020[cited 2021 Sep 28];15(11):e0242905. Available from: https://www.ncbi.nlm. nih.gov/pmc/articles/PMC7688124/pdf/pone.0242905.pdf doi: 10.1371/journal.pone.0242905

34. Dhillon J, Salimi A, ElHawary H. Impact of COVID-19 on Canadian Medical Education: Pre-clerkship and Clerkship Students Affected Differently. J Med Educ Curric Dev [Internet]. 2020[cited 2021 Sep 30];7:2382120520965247. Available from: https://www.ncbi.nlm.nih.gov/pmc/articles/ PMC7576927/pdf/10.1177_2382120520965247.pdf doi: $10.1177 / 23821205209652 \overline{47}$

35. Tapper J, Batty D, Savage,M. Medical students take final exams online for first time, despite student concern. Guardian News [Internet]. 2020[cited 2021 Sep 30]. Available from: https://www. theguardian.com/education/2020/mar/22/coronavirus-forcesmedical-students-sit-final-exams-online

36. Arandjelovic A, Arandjelovic K, Dwyer K, Shaw C. COVID-19: Considerations for Medical Education during a Pandemic. MedEdPublish [Internet]. 2020[cited 2021 Sep 30]. Available from: https://www.mededpublish.org/manuscripts/3082 doi: 10.15694/mep.2020.000087.1

37. Munshi F, Alsughayyer A, Alhaidar S, Alarfaj M. An Online Clinical Exam for Fellowship Certification during COVID-19 Pandemic. Med Educ. 2020;54(10):954-5. doi: 10.1111/ medu. 14267

\section{References}

1. Woolliscroft JO. Innovation in Response to the COVID-19 Pandemic Crisis. Acad Med. 2020;95(8):1140-2. doi: 10.1097/ ACM.0000000000003402

2. Calhoun KE, Yale LA, Whipple ME, Allen SM, Wood DE, Tatum RP. The impact of COVID-19 on medical student surgical education: Implementing extreme pandemic response measures in a widely distributed surgical clerkship experience. Am J Surg. 2020;220(1):44-7. doi: 10.1016/j.amjsurg.2020.04.024

3. Sklar DP. COVID-19: Lessons From the Disaster That Can Improve Health Professions Education. Acad Med. 2020;95(11):1631-3. doi: 10.1097/ACM.0000000000003547

4. Akers A, Blough C, Iyer MS. COVID-19 Implications on Clinical Clerkships and the Residency Application Process for Medical Students. Cureus [Internet]. 2020[cited 2021 Sep 27];12(4):e7800. Available from: https:/www.ncbi.nlm.nih.gov/ pmc/articles/PMC7243841/pdf/cureus-0012-00000007800.pdf doi: $10.7759 /$ cureus. 7800

5. Khasawneh AI, Humeidan AA, Alsulaiman JW, Bloukh S, Ramadan M, Al-Shatanawi TN, et al. Medical Students and COVID-19: Knowledge, Attitudes, and Precautionary Measures. A Descriptive Study From Jordan. Front Public Health [Internet]. 2020[cited 2021 Sep 30];8:253. Available from: https://www.ncbi. nlm.nih.gov/pmc/articles/PMC7274076/pdf/fpubh-08-00253.pdf doi: 10.3389/fpubh.2020.00253

6. Ross DA. Creating a "Quarantine Curriculum" to Enhance Teaching and Learning During the COVID-19 Pandemic. Acad Med. 2020;95(8):1125-6. doi: 10.1097/ACM.0000000000003424

7. Longhurst GJ, Stone DM, Dulohery K, Scully D, Campbell T, Smith CF. Strength, Weakness, Opportunity, Threat (SWOT) analysis of the adaptations to anatomical education in the United Kingdom and Republic of Ireland in response to the Covid-19 
pandemic. Anat Sci Educ. 2020;13(3):301-11. doi: 10.1002/ ase. 1967

8. Fernandez AA, Shaw GP. Academic leadership in a time of crisis: the coronavirus and COVID-19. J Leadersh Stud. 2020;14(1):3945. doi: $10.1002 / \mathrm{jls} .21684$

9. The University of the West Indies. UWI shares changes to teaching, exams amid COVID-19 [Internet]. Loop News; 2020[cited 2021 Sep 25]. Available from: https://tt.loopnews. com/content/uwi-shares-changes-teaching-exams-amid-covid-19

10. Yurttas IS, Aktar I, Bardak M, Goeschl S. Institutional report for COVID-19 impact on medical education [Internet]. European Medical Students' Association; 2020[cited 2021 Sep 27]. Available from: https://medisep.org/mediblog-blog10

11. Dedeilia A, Sotiropoulos MG, Hanrahan JG, Janga D, Dedeilias P, Sideris M. Medical and surgical education challenges and innovations in the COVID-19 era: a systematic review. In Vivo. 2020;34(3 Suppl):1603-11. doi: 10.21873/invivo.11950

12. Representatives of the STARSurg Collaborative. Medical student involvement in the COVID-19 response. Lancet. 2020;395(10232):1254. doi: 10.1016/S0140-6736(20)30795-9

13. Rose S. Medical student education in the time of COVID-19. JAMA. 2020;323(21):2131-2. doi: 10.1001/jama.2020.5227

14. Stowell JR, Bennett D. Effects of online testing on student exam performance and test anxiety. J Educ Comput Res. 2010;42(2):161-71. doi: 10.2190/EC.42.2.b

15. Wolanskyj-Spinner AP. COVID-19: the global disrupter of medical education [Internet]. 2020[cited 2021 Sep 30]. Available from: https://www.ashclinicalnews.org/viewpoints/editorscorner/covid-19-global-disrupter-medical-education/

16. Waghmare PP, Gupta A. Challenges and Solutions to Continuing Medical Education amid Novel Coronavirus Disease (COVID-19) Pandemic and National Lockdown in India. MedEdPublish [Internet]. 2020[cited 2021 Sep 27]. Available from: https:// www.mededpublish.org/manuscripts/3346 doi: 10.15694/ mep.2020.000219.1

17. Torda AJ, Velan G, Perkovic V. The impact of Covid-19 pandemic on medical education. Med J Aust. 2020;213(7):334. doi: $10.5694 / \mathrm{mja} 2.50762$

18. Goh PS, Sandars J. A vision of the use of technology in medical education after the COVID-19 pandemic. MedEdPublish [Internet]. 2020[cited 2021 Sep 27];9(1):49. Available from: https://www.mededpublish.org/manuscripts/2943 doi: 10.15694/ mep.2020.000049.1

19. Gallagher TH, Schleyer AM. "We signed up for this!" Student and trainee responses to the Covid-19 pandemic. $\mathrm{N}$ Engl J Med [Internet]. 2020[cited 2021 Sep 30];382(25):e96. Available from: https://www.nejm.org/doi/pdf/10.1056/ NEJMp2005234? articleTools=true doi: 10.1056/nejmp2005234

20. Liang ZC, Ooi SBS, Wang W. Pandemics and their impact on medical training: lessons from Singapore. Acad Med [Internet]. 2020[cited 2021 Sep 25];20(10). Available from: https://www. ncbi.nlm.nih.gov/pmc/articles/PMC7188065/ doi: 10.1097/ ACM.0000000000003441

21. Pather N, Blyth P, Chapman JA, Dayal MR, Flack NAMS, Fogg QA, et al. Forced disruption of anatomy education in Australia and New Zealand: an acute response to the Covid-19 pandemic. Nat Sci Educ. 2020;13(3):284-300. doi: 10.1002/ase.1968

22. Franchi T. The impact of the Covid-19 pandemic on current anatomy education and future careers: a student's perspective. Anat Sci Educ. 2020;13(3):312-5. doi: 10.1002/ase.1966

23. Doubleday EG, O'Loughlin VD, Doubleday AF. The virtual anatomy laboratory: usability testing to improve an online learning resource for anatomy education. Anat Sci Educ. 2011;4(6):318-
26. doi: $10.1002 /$ ase. 252

24. Saverino D. Teaching anatomy at the time of COVID-19. Clin Anat [Internet]. 2020[cited 2021 Sep 30]. Available from: https:// www.ncbi.nlm.nih.gov/pmc/articles/PMC7267360/pdf/CA9999-na.pdf doi: 10.1002/ca.23616

25. Bao W. COVID-19 and online teaching in higher education: a case study of Peking University. Hum Behav Emerg Technol. 2020;2(2):113-5. doi: 10.1002/hbe2.191

26. Watson A, McKinnon T, Prior S-D, Richards L, Green CA. COVID-19: time for a bold new strategy for medical education. Med Educ Online [Internet]. 2020[cited 2021 Sep 27];25(1):1764741. Available from: https://www.ncbi.nlm.nih. gov/pmc/articles/PMC7269071/pdf/ZMEO_25_1764741.pdf doi: $10.1080 / 10872981.2020 .1764741$

27. Samaraee AA. The impact of the COVID-19 pandemic on medical education. Br J Hosp Med (Lond). 2020;81(7):1-4. doi: 10.12968/hmed.2020.0191

28. Emanuel EJ. The Inevitable Reimagining of Medical Education. JAMA. 2020;323(12):1127-8. doi: 10.1001/jama.2020.1227

29. Candler C. Effective use of educational technology in medical education. Colloquium on educational technology: recommendations and guidelines for medical educators. Washington: Association of American Medical Colleges; 2007. $19 \mathrm{p}$.

30. Sam AH, Millar KR, Lupton MGF. Digital Clinical Placement for Medical Students in Response to COVID-19. Acad Med [Internet]. 2020[cited 2021 Sep 25]. Available from: https://www. ncbi.nlm.nih.gov/pmc/articles/PMC7179062/ doi: 10.1097/ ACM.0000000000003431

31. Hollander JE, Carr BG. Virtually Perfect? Telemedicine for Covid-19. N Engl J Med. 2020;382(18):1679-81. doi: 10.1056/ nejmp2003539

32. Chandra S, Laoteppitaks C, Mingioni N, Papanagnou D. ZoomingOut COVID: Virtual Clinical Experiences in an Emergency Medicine Clerkship. Medical Education. 2020;54(12):11823. doi: 10.1111/medu.14266

33. Alsoufi A, Alsuyihili A, Msherghi A, Elhadi A, Atiyah H, Ashini A, et al. Impact of the COVID-19 pandemic on medical education: Medical students' knowledge, attitudes, and practices regarding electronic learning. PLoS One [Internet]. 2020[cited 2021 Sep 28];15(11):e0242905. Available from: https://www.ncbi.nlm. nih.gov/pmc/articles/PMC7688124/pdf/pone.0242905.pdf doi: 10.1371/journal.pone.0242905

34. Dhillon J, Salimi A, ElHawary H. Impact of COVID-19 on Canadian Medical Education: Pre-clerkship and Clerkship Students Affected Differently. J Med Educ Curric Dev [Internet]. 2020[cited 2021 Sep 30];7:2382120520965247. Available from: https://www.ncbi.nlm.nih.gov/pmc/articles/ PMC7576927/pdf/10.1177 2382120520965247.pdf doi: $10.1177 / 2382120520965247$

35. Tapper J, Batty D, Savage,M. Medical students take final exams online for first time, despite student concern. Guardian News [Internet]. 2020[cited 2021 Sep 30]. Available from: https://www. theguardian.com/education/2020/mar/22/coronavirus-forcesmedical-students-sit-final-exams-online

36. Arandjelovic A, Arandjelovic K, Dwyer K, Shaw C. COVID-19: Considerations for Medical Education during a Pandemic. MedEdPublish [Internet]. 2020[cited 2021 Sep 30]. Available from: https://www.mededpublish.org/manuscripts/3082 doi: 10.15694/mep.2020.000087.1

37. Munshi F, Alsughayyer A, Alhaidar S, Alarfaj M. An Online Clinical Exam for Fellowship Certification during COVID-19 Pandemic. Med Educ. 2020;54(10):954-5. doi: 10.1111/ medu. 14267 


\section{Відомості про авторів:}

Поясник І. М. - к.мед.н., в.о.доцента кафедри неврології та нейрохірургії, Івано-Франківський національний медичний університет, м. Івано-Франківськ, Україна.

Гриб В.А. - д.мед.н., професор, завідувач кафедри неврології та нейрохірургії, Івано-Франківський національний медичний університет, м. Івано-Франківськ, Україна.

\section{Сведения об авторах:}

Пояснык И. М. - к.мед.н., и.о. доцента кафедры неврологии и нейрохирургии, Ивано-Франковский национальный медицинский университет, г. Ивано-Франковск, Украина.

Грыб В.А. - д.мед.н., профессор, заведующий кафедрой неврологии и нейрохирургии, Ивано-Франковский национальный медицинский университет, г. Ивано-Франковск, Украина.

\section{Information about authors:}

Poiasnyk I. M. - PhD, Associate Professor of the Department of neurology and neurosurgery, Ivano-Frankivsk National Medical University, Ivano-Frankivsk, Ukraine.

V.A. Gryb - MD, PhD, Professor, Head of the Department of neurology and neurosurgery, Ivano-Frankivsk National Medical University, Ivano-Frankivsk, Ukraine. 